\title{
Efektivitas Terapi Wudhu Menjelang Tidur terhadap Kualitas Tidur Remaja
}

\author{
The Effectiveness of Wudhu Therapy before Bedtime into Sleep Qualtiy in Teenagers \\ Nina Dwi Lestari ${ }^{1 *}$, Muhammad Rofiqul Minan ${ }^{1}$ \\ ${ }^{1}$ Program Studi IImu Keperawatan Fakultas Kedokteran dan IImu Kesehatan, Universitas Muhammadiyah Yogyakarta
}

\section{DATA NASKAH:}

Received: 09 Jan 2018

Reviewed: 18 Mar 2018

Revised: 02 Apr 2018

Accepted: 10 May 2018

\section{*KORESPONDENSI:}

ninadwilestari@umy.ac.id

DOI:

10.18196/mm.180215

\section{TIPE ARTIKEL:}

Penelitian

\begin{abstract}
Abstrak: Gangguan kualitas tidur memberikan dampak buruk terhadap kesehatan dan menurunnya konsentrasi seseorang. Penelitian mengenai terapi relaksasi khususnya wudhu terhadap kualitas tidur remaja belum pernah dilakukan. Penelitian ini bertujuan untuk mengetahui efektifitas terapi wudhu menjelang tidur terhadap kualitas tidur pada remaja. Penelitian ini adalah Quasy-Experimental with pretest-posttest control group design pada 60 remaja.Teknik sampling dengan Simple Random Sampling. Instrumen yang digunakan adalah Pittsburgh Sleep Quality Index (PSQI). Pretest dilakukan pada kedua kelompok selama 7 hari sebelum perlakuan dimulai pada kelompok intervensi. Terapi wudhu dilakukan pada kelompok eksperimen, sekali sehari setiap hari menjelang tidur malam selama seminggu. Posttest dilakukan setiap hari selama seminggu, dilakukan saat bangun tidur (pagi hari) pada kedua kelompok, selama intervensi berlangsung pada kelompok eksperimen. Uji statistik menggunakan uji T. Hasil penelitian menunjukkan nilai rata-rata PSQI sebelum dan sesudah diberikan terapi wudhu yaitu 6.04 dan 3.94 (p value 0,000$)$. Rata-rata nilai PSQI pada kelompok kontrol pada pengukuran pertama adalah 6.23 dan 6.05 pada pengukuran kedua ( $\mathrm{p}$ value 0,730 ). Terdapat perbedaan kualitas tidur yang signifikan antara kelompok control dan kelompok eksperimen setelah diberikan terapi wudhu ( $p$ value $0,000, p<0,05$ ). Terapi wudhu menjelang tidur terbukti efektif dalam meningkatkan kualitas tidur remaja.
\end{abstract}

Kata kunci: Wudhu; Terapi; Kualitas Tidur; Remaja

Abstract: Sleep quality disorder have a serious impact on well-being and concentration. Research on wudhu therapy in teen's sleep quality has never been done. The aim of this study was to examine the effectiveness of wudhu therapy to improving teen's sleep quality. This is Quasy-Experimental with pretest-posttest control group design in 60 teenagers taken by Simple Random Sampling. Research instrument is Pittsburgh Sleep Quality Index (PSQI). Pretest conducted in both of groups during the 7 days before treatment started. Wudhu therapy performed on experiment group, once a day, every day for a week before the night's sleep. Posttest performed daily for a week when waking up (morning) in two groups, during an intervention in the experiment group. Statistical tests using $T$ test. The results showed that mean value of PSQI before and after given wudhu therapy are 6.04 and 3.94 respectively ( $p$ value 0.000). Mean value of PSQI in control group at the first and second measurements are 6.05 and 6.23 respectively ( $p$ value 0.730 ). There is a significant differences in sleep quality between experiment and control group ( $p$ value 0.000, $p<0.05$ ). Wudhu therapy proven to be effective towards improving teen's sleep quality.

Key words: Wudhu; Therapy; Sleep Quality; Teen 


\section{PENDAHULUAN}

Tidur merupakan salah satu kebutuhan dasar setiap manusia yang berperan penting dalam meningkatkan stabilitas daya tahan tubuh. ${ }^{1}$ Manfaat tidur dapat dirasakan secara optimal apabila tidur tersebut memiliki kualitas dan kuantitas yang baik. ${ }^{2}$ Adanya gangguan dalam kualitas tidur yang diakibatkan oleh stres, insomnia, mimpi buruk, diabetes, tersumbatnya saluran pernapasan, akan membuat kualitas tidur menjadi buruk sehingga ketika bangun, tubuh dalam kondisi yang tidak segar bugar. $^{3}$

Gangguan dalam kualitas tidur dialami oleh berbagai tingkatan usia, salah satunya adalah remaja. Penelitian yang dilakukan oleh Haryono et al. (2009), ${ }^{4}$ menunjukkan bahwa prevalensi gangguan tidur pada remaja adalah sebesar 62,9\%. Prevalensi gangguan tidur pada remaja di Indonesia berkisar $25 \%-40 \% .^{5}$ Kualitas tidur yang buruk pada remaja dapat mengakibatkan penurunan kinerja otak, dan menurunnya tingkat konsentrasi. ${ }^{6}$

Hasil survey pendahuluan pada mahasiswa keperawatan tingkat akhir di Universitas Muhammadiyah Yogyakarta (UMY) menunjukkan bahwa 81,3\% mahasiswa mengeluhkan gangguan tidur yang diakibatkan oleh beban tugas kuliah. Gangguan dalam kualitas tidur tersebut menyebabkan kurang konsentrasi dan keluhan fisik. Upaya yang sudah dilakukan adalah dalam bentuk mendengarkan musik, mendengarkan murotal, dzikir dan pijat, akan tetapi hanya 19,2\% mahasiswa yang menyatakan cara tersebut efektif dalam meningkatkan kualitas tidurnya.

Gangguan dalam kualitas tidur dapat diatasi dengan berbagai cara, diantaranya adalah melalui terapi relaksasi. Beberapa penelitian sebelumnya telah membuktikan bahwa relaksasi sebelum tidur dapat meningkatkan kualitas tidur. Relaksasi yang biasa dilakukan saat menjelang tidur yang terbukti memberikan pengaruh dalam peningkatan kualitas tidur adalah teknik relaksasi aroma terapi, ${ }^{7}$ terapi musik, ${ }^{8}$ terapi back massage. ${ }^{9}$ Upaya dalam meningkatkan kualitas tidur dalam bentuk terapi relaksasi lain yang dimungkinkan efektif adalah wudhu. Penelitian membuktikan bahwa wudhu memiliki manfaat dalam mengatasi masalah gangguan tidur. ${ }^{10}$

Wudhu merupakan salah satu bentuk terapi yang dapat meningkatkan fungsi neurologis. ${ }^{11}$ Air wudhu yang digunakan, dapat bermanfaat dalam mendinginkan ujung saraf jari tangan dan kaki yang akan memberikan manfaat dalam memantapkan konsentrasi dan membuat tubuh menjadi rileks. Saat melakukan gerakan wudhu akan memberikan efek masage (pijatan) pada anggota tubuh yang dibasuh, efek masage dapat mendorong tubuh untuk mengeluarkan hormon endorfin yang mem-

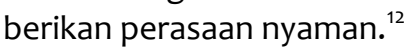

Penelitian mengenai manfaat wudhu untuk kesehatan sudah banyak diteliti, akan tetapi penelitian mengenai efektifitas wudhu sebagai terapi relaksasi untuk meningkatkan kualitas tidur, masih belum banyak diteliti. Penelitian ini bertujuan untuk mengetahui efektifitas terapi wudhu terhadap kualitas tidur khususnya pada remaja.

\section{BAHAN DAN CARA}

Metode penelitian ini adalah kuantitatif dengan desain quasy experimental, pretest posttest with control group design. Populasi penelitian ini adalah remaja yang berjumlah 120 orang. Jumlah sampel yang diikutkan dalam penelitian ini adalah sebanyak 60 responden, yang terbagi menjadi 30 responden yang termasuk dalam kelompok eksperimen dan 30 responden lainnya sebagai kelompok kontrol. Teknik sampling menggunakan simple random sampling. Instrumen yang digunakan berupa kuesioner Pittsburgh Sleep Quality Index (PSQI) dalam versi Bahasa Indonesia, yang telah teruji validitas dan reliabilitas oleh penelitian sebelumnya di Indonesia yaitu oleh Agustin (2012), ${ }^{13}$ dengan nilai $r$ hitung $>0,361$ pada $n=30$, dan dengan koefisien Cronbach's Alpha sebesar 0,766 (>0,7). PSQI digunakan untuk menilai kualitas tidur pada saat pretest dan posttest.

Pretest dilakukan pada kedua kelompok selama 7 hari sebelum perlakuan dimulai pada kelompok intervensi. Terapi wudhu dilakukan menjelang tidur malam oleh responden secara mandiri, setiap hari selama 1 minggu, pada kelompok eksperimen. Posttest dilakukan setiap hari selama 7 hari, dilakukan pada saat bangun tidur (pagi hari) pada kedua kelompok, dilakukan selama intervensi berlangsung pada kelompok eksperimen. Pengukuran nilai posttest dimulai ketika intervensi mulai dilakukan pada kelompok eksperimen. Responden pada kelompok eksperimen, diberikan lembar monitoring untuk mengecek pelaksanaan terapi wudhu selama penelitian berlangsung.

Nilai PSQI yang merupakan hasil pretest dan posttest berupa data ratio dalam rentang nilai antara 0-21. Semakin tinggi nilai PSQI, menunjukkan bahwa kualitas responden semakin buruk. Uji statis- 
tik yang digunakan adalah Uji T (independent dan paired $T$ test). Independent $t$ test digunakan untuk melihat perbedaan nilai pretest dan posttest pada kelompok eksperimen dan kelompok kontrol. Paired $t$ test digunakan untuk melihat perbedaan nilai pretest dan posttest dalam kelompok yang sama. Penelitian ini telah dinyatakan lulus uji etik di Fakultas Kedokteran dan IImu Kesehatan, UMY dengan nomor etik 189/EP-FKIK-UMY/III/2017.

\section{HASIL}

Berdasarkan karakteristik responden, mayoritas responden berjenis kelamin perempuan, baik pada kelompok eksperimen (83,3\%), maupun kelompok kontrol $(66,7 \%)$. Berdasarkan usia, semua responden pada kelompok intervensi berusia 22 tahun dan hampir semua responden kelompok kontrol berusia 22 tahun (96,7\%). Secara jelas dapat dilihat pada Tabel 1.

Berdasarkan Tabel 2. dapat dilihat bahwa pada kelompok intervensi terdapat nilai rata-rata pretest PSQI yaitu 6,04 sedangkan nilai rata-rata posttest PSQI setelah diberikan terapi wudhu mengalami penurunan menjadi 3,94 dengan $p$ value 0.000 $(p<0,05)$. Hal ini menunjukkan bahwa terdapat perbedaan yang signifikan pada tingkat kualitas tidur antara sebelum dan sesudah diberikan terapi wudhu. Kesimpulannya, kualitas tidur mahasiswa meningkat setelah dilakukan tindakan wudhu menjelang tidur. Nilai rata-rata PSQI pada kelompok

Tabel 1. Gambaran Karakteristik Responden

\begin{tabular}{lcccc}
\hline $\begin{array}{c}\text { Karakteristik } \\
\text { Responden }\end{array}$ & \multicolumn{2}{c}{$\begin{array}{c}\text { Kelompok } \\
\text { intevensi }\end{array}$} & \multicolumn{2}{c}{$\begin{array}{c}\text { Kelompok } \\
\text { kontrol }\end{array}$} \\
\cline { 2 - 5 } & $\mathrm{N}$ & $\%$ & $\mathrm{~N}$ & $\%$ \\
\hline Jenis kelamin & & & & \\
$\quad$ Laki-laki & 5 & 16,7 & 10 & 33,3 \\
$\quad$ Perempuan & 25 & 83,3 & 20 & 66,7 \\
Jumlah & 30 & 100 & 30 & 100 \\
Usia & & & & \\
22 tahun & 30 & 100 & 29 & 96,7 \\
23 tahun & 0 & 0 & 1 & 3,3 \\
Jumlah & 30 & 100 & 30 & 100 \\
\hline
\end{tabular}

Tabel 2. Hasil Uji Statistik Paired T-Test Perbedaan Nilai Pretest-Postest Kualitas Tidur Remaja pada Masing-masing Kelompok Intervensi dan Kontrol

\begin{tabular}{llll}
\hline \multirow{2}{*}{ Kelompok } & \multicolumn{1}{c}{ Pretest } & \multicolumn{1}{c}{ Postest } & \multirow{2}{*}{ P value } \\
\cline { 2 - 3 } & Mean \pm SD & Mean \pm SD & \\
\hline Intervensi & $6.04 \pm 1.67$ & $3.94 \pm 1.06$ & 0.000 \\
Kontrol & $6.23 \pm 1.89$ & $6.05 \pm 2.17$ & 0.730 \\
\hline
\end{tabular}

Tabel 3. Hasil Uji Statistik Independent T-Test Perbedaan Nilai Pretest dan Perbedaan Hasil Posttest Kualitas Tidur antara Kelompok Intervensi dan Kelompok Kontrol

\begin{tabular}{lccc}
\hline & $\begin{array}{c}\text { Kontrol } \\
\text { (mean) }\end{array}$ & $\begin{array}{c}\text { Intervensi } \\
\text { (mean) }\end{array}$ & $\begin{array}{c}P \\
\text { value }\end{array}$ \\
\hline Pretest & 6.23 & 6.04 & 0.674 \\
Posttest & 6.05 & 3.94 & 0.000 \\
\hline
\end{tabular}

kontrol saat pengukuran pertama yaitu 6,23 dan nilai rata-rata PSQI pada pengukuran kedua, hasilnya tidak jauh berbeda yaitu 6,05. Hasil uji statistik menunjukkan nilai $p$ sebesar 0.730 ( $p>0.05)$. Hal ini berarti bahwa tidak terdapat perbedaan yang signifikan antara skor PSQI pada saat pengukuran pertama dan pengukuran kedua. Kualitas tidur mahasiswa tidak mengalami peningkatan tanpa melakukan wudhu menjelang tidur.

Berdasarkan Tabel 3. dapat dilihat bahwa nilai rata-rata kualitas tidur pada saat pretest pada kelompok intervensi dan kelompok kontrol tidak menunjukkan perbedaan yang signifikan ( $p$ value 0,674, p>0,05). Hasil ini berseberangan dengan nilai rata-rata posttest pada kelompok intervensi dan kontrol. Hasil uji statistik menggunakan independent $t$-test menunjukkan nilai $p$ value $0.000(p<0.05)$ yang artinya terdapat perbedaan yang signifikan antara nilai PSQI pada kelompok intervensi setelah diberikan terapi wudhu dan nilai PSQI pengukuran kedua pada kelompok kontrol.

\section{DISKUSI}

Hasil analisis terhadap karakteristik responden berdasarkan usia pada penelitian ini menunjukkan bahwa responden berada pada rentang usia 22-23 tahun. Menurut WHO, usia 19-25 tahun merupakan usia remaja akhir dimana terjadi perubahan menuju dewasa. Remaja merupakan masa peralihan dari suatu tahap ke tahap berikutnya dan penuh dengan masalah serta mengalami perubahan baik emosi, tubuh dan perilaku. ${ }^{10}$ Responden pada penelitian ini merupakan remaja akhir dan berada dalam tahap akhir jenjang pendidikan yaitu mahasiswa tingkat akhir keperawatan dimana terdapat banyak tekanan baik dari beban perkuliahan, praktikum, tutorial dan ditambah dengan beban tugas akhir berupa Karya Tulis Ilmiah (KTI) sebagai syarat agar mahasiswa lulus sebagai sarjana S1 keperawatan. Mahasiswa tingkat akhir dituntut untuk menyelesaikan tugas akhir tepat waktu agar dapat lulus tepat waktu. 
Berdasarkan karakteristik jenis kelamin, responden pada penelitian ini paling banyak yaitu berjenis kelamin perempuan. Jenis kelamin merupakan salah satu faktor yang mempengaruhi kualitas tidur seseorang. Hal ini berkaitan dengan pendapat bahwa perempuan sangat memiliki tingkat kecemasan yang lebih tinggi dan lebih sensitif dibandingkan dengan laki-laki. ${ }^{14}$ Seseorang yang sedang mengalami cemas, akan berpengaruh terhadap kualitas tidurnya. Kecemasan responden pada penelitian ini disebabkan karena responden sedang mengerjakan tugas akhir berupa KTI. Hal ini sejalan dengan penelitian yang dilakukan oleh Albar (2014), ${ }^{15}$ tentang hubungan antara kecemasan dengan kualitas tidur mahasiswa selama penyusunan skripsi di STIKES 'Aisyiyah Yogyakarta. Hasil penelitian ini menunjukkan bahwa mayoritas responden berjenis kelamin perempuan (72,9\%) dan menunjukkan bahwa kualitas tidur mahasiswa dipengaruhi oleh kecemasan yang dialami mahasiswa.

Hasil penelitian ini berseberangan dengan hasil penelitian yang dilakukan oleh Nashori dan Diana (2012), ${ }^{16}$ bahwa mahasiswa perempuan memiliki kualitas tidur yang lebih tinggi disbandingkan dengan mahasiswa laki-laki. Hal ini terjadi karena pada mahasiswa laki-laki lebih cenderung memulai tidur di waktu yang sudah sangat larut. Mayoritas mahasiswa laki-laki memulai tidur ketika waktu menunjukkan pukul 12 malam, sedangkan pada mahasiswa perempuan memiliki kebiasaan tidur yang lebih baik yaitu tidur pada waktu yang lebih awal.

Berdasarkan hasil uji statistik menggunakan uji paired t-Test menunjukkan bahwa terdapat perbedaan yang signifikan terkait nilai PSQI pada kelompok intervensi, sebelum dan setelah melakukan wudhu dengan $p$ value 0,000. Hal ini menunjukkan adanya peningkatan kualitas tidur setelah melakukan wudhu menjelang tidur.

Berdasarkan data yang disajikan pada Tabel 2 . hasil uji paired t-Test menunjukkan tidak terdapat perbedaan yang signifikan antara nilai PSQI saat pengukuran pertama dengan pengukuran ke dua pada kelompok kontrol ( $p$ value 0,730). Hal ini menunjukkan tidak terdapat perbedaan yang signifikan pada kualitas tidur pada saat pengukuran pertama dan kedua, di kelompok kontrol.

Hasil dari uji Independent t-Test kelompok intervensi dengan kelompok kontrol pada pretest menunjukkan nilai signifikansi $p$ 0,674 hal ini menunjukkan bahwa kualitas tidur pada kedua kelompok memiliki kesamaan atau tidak adanya perbe- daan dalam kualitas tidur. Hasil uji independent $t$ Test kelompok intervensi dengan kelompok kontrol pada saat posttest memiliki nilai signifikansi $p 0,000$ (<0.05). Hal ini menunjukkan adanya perbedaan antara kelompok intervensi setelah melakukan wudhu menjelang tidur dengan kelompok kontrol pada pengukuran kedua.

Berdasarkan hasil tersebut dapat disimpulkan bahwa terapi wudhu menjelang tidur terbukti efektif dalam meningkatkan kualitas tidur remaja. Hasil penelitian ini didukung oleh penelitian Hariawan (2015), ${ }^{17}$ mengenai pengaruh berwudhu terhadap kualitas tidur lansia insomnia di PSTW Puspakarma Mataram. Hasil uji Paired t-test menunjukkan hasil yang signifikan ketika sebelum dan sesudah diberikan intervensi pada kelompok intervensi dengan hasil $p$ value $0.031(p<0,05)$. Hasil dari nilai $p$ tersebut menunjukkan bahwa setelah dilakukan intervensi berupa wudhu pada kelompok intervensi, terjadi penurunan skor pada pengukuran kualitas tidur PSQI sehingga setelah dilakukan wudhu kualitas tidur pada lansia membaik. Hal ini diperkuat kembali dengan penelitian yang dilakukan oleh Rinawati (2012), ${ }^{18}$ bahwa tidak terdapat perubahan tingkat insomnia pada kelompok kontrol yang tidak diberikan intervensi berupa wudhu menjelang tidur.

Wudhu memberikan ketenangan yang dimaknai seperti perasaan nyaman, damai, tentram dan merasa bahagia karena wudhu juga meringankan fungsi jantung dan memperlancar aliran darah. ${ }^{19}$ Pada saat melakukan wudhu terdapat efek masage (pijatan) yang dapat mendorong tubuh untuk mengeluarkan hormon endorfin yang memberikan rasa nyaman. Saat tubuh dalam keadaan nyaman, saraf yang bekerja yaitu parasimpatik yang akan menurunkan semua fungsi yang dinaikkan oleh saraf simpatik sehingga terjadi relaksasi. ${ }^{12}$

Relaksasi memberikan dampak pada tubuh dan pikiran menjadi rileks sehingga memudahkan seseorang untuk masuk ke kondisi tidur dan meningkatkan kualitas tidur. ${ }^{18} \mathrm{Hal}$ ini sejalan dengan penelitian yang dilakukan oleh Saputro (2015), ${ }^{11}$ tentang pengaruh terapi wudhu sebelum tidur terhadap tingkat insomnia pada usia lanjut di PSTW Unit Budi Luhur Yogyakarta didapatkan hasil nilai $p$ $0.000(p<0.05)$ yang artinya bahwa wudhu secara signifikan berpengaruh terhadap penurunan tingkat insomnia pada lansia.

Wudhu dapat memberikan manfaat yang sangat besar bagi kesehatan tubuh, salah satunya yaitu mengatasi masalah gangguan tidur. Setiap gerakan wudhu memiliki manfaat yang mendukung 
tubuh meningkatkan kualitas tidur, seperti ketika melakukan gerakan membasuh tangan kemudian menggosok sela-sela jari, bermanfaat untuk memperlancar aliran darah perifer sehingga pasokan oksigen menjadi terpenuhi dan air yang mengalir memberikan efek menenangkan. ${ }^{10}$ Saat seseorang sedang berkumur, otot-otot wajah akan bergerak sehingga dapat memberikan efek relaksasi pada wajah. ${ }^{20}$ Saat membasuh muka, tangan dan kepala dapat mengurangi dan menghilangkan kecemasan, depresi dan stress. ${ }^{21}$ Saat membasuh telinga, ketika seseorang menggosok telinga dengan lembut dapat meningkatkan tingkat konsentrasi. ${ }^{22}$ Pada saat membasuh kaki akan memperlancar peredaran darah di kaki, karena kaki merupakan organ yang paling jauh dari jantung. ${ }^{21}$

Berdasarkan penjelasan tersebut dapat dilihat bahwa wudhu memiliki banyak manfaat bagi kesehatan, khususnya memiliki efek terhadap relaksasi tubuh. Kondisi tubuh yang rileks pada akhirnya dapat menjadikan kualitas tidur seseorang semakin membaik. Hasil penelitian ini membuktikan bahwa terapi wudhu yang dilakukan menjelang tidur, dapat meningkatkan kualitas tidur mahasiswa keperawatan di Universitas Muhammadiyah Yogyakarta.

\section{SIMPULAN}

Wudhu menjelang tidur terbukti secara efektif dapat meningkatkan kualitas tidur mahasiswa Keperawatan di Universitas Muhammadiyah Yogyakarta.

\section{DAFTAR PUSTAKA}

1. Bajry AH. Tubuh Anda Adalah Dokter yang Terbaik. Purwakarta: Media Holistic Indonesia. 2013.

2. Riyadi S \& Widuri H. Kebutuhan Dasar Manusia Aktivitas Istirahat: Diagnosa NANDA. Yogyakarta: Gosyen Publishing. 2015.

3. Robotham D. Sleep as a Public Health Concern: Insomnia and Mental Health. J Public Mental Health, 2011; 10 (4): 234-237.

4. Haryono A, Rindiarti A, Arianti A, Pawitri A, Ushuluddin A, Setiawati A, et al. Prevalensi Gangguan Tidur pada Remaja Usia 12-15 Tahun di Sekolah Lanjutan Tingkat Pertama. Naskah Publikasi. Fakultas Kedokteran Universitas Indonesia. 2009.

5. Harmoniati DE, Sekartini $\mathrm{R} \&$ Gunardi $H$. Intervensi Sleep Hygine pada Anak Usia Sekolah dengan Gangguan Tidur. Sari Pediatri. Departemen
Ilmu Kesehatan Anak Fakultas Kedokteran Universitas Indonesia, 2016; 18 (2): 93-9.

6. Sarfriyanda J, Karim D, Dewi AP. Hubungan antara Kualitas Tidur dan Kuantitas Tidur dengan Prestasi Belajar Mahasiswa. JOM, 2015; 2 (2): 1178-85.

7. Alissa D. Pengaruh Pemberian Aroma Terapi Lemon (Citrus lemon) terhadap Kualitas Tidur pada Lansia. Karya Tulis Ilmiah Strata Satu. Universitas Muhammadiyah Yogyakarta. 2015.

8. Anggraeny. Pengaruh Terapi Musik Pop terhadap Kualitas Tidur Anak Usia Sekolah (6-12 Tahun) yang Dirawat di RSUD Ambarawa. Skripsi tidak diterbitkan: Universitas Diponegoro. 2014.

9. Marethidta CA. Pengaruh Back Massage Durasi 20 Menit dan 40 Menit untuk Meningkatkan Kualitas Tidur. Skripsi Strata Satu. Universitas Muhammadiyah Surakarta. 2013.

10. Utami AS. Pengaruh Berwudhu terhadap Tingkat Kecemasan pada Siswa SMA yang Menghadapi Ujian Nasional. Karya Tulis Ilmiah Strata Satu. Universitas Muhammadiyah Yogyakarta. 2016.

11. Saputro DA. Pengaruh Terapi Wudhu sebelum Tidur terhadap Tingkat Insomnia pada Lanjut Usia di PSTW Unit Budhi Luhur Yogyakarta. Skripsi Strata Satu. Sekolah Tinggi Ilmu Kesehatan 'Aisyiyah Yogyakarta. 2015.

12. Potter \& Perry. Fundamental of Nursing: Concept, Process and Practice. Edisi 7. Vol 3: Jakarta: EGC. 2010.

13. Agustin D. Faktor-faktor yang Mempengaruhi Kualitas Tidur pada Pekerja Shift di PT Krakatau Tirta Industri Cilegon. Skripsi Strata Satu. Fakultas Ilmu Keperawatan Universitas Indonesia. 2012

14. Agustiar W \& Asmi Y. Kecemasan Menghadapi Ujian Nasional dan Motivasi Belajar pada Siswa Kelas XII SMA Negeri X Jakarta Selatan. Jurnal Psikologi, 2010; 8 (1): 9-15.

15. Albar. Hubungan antara Kecemasan dengan Kualitas Tidur Mahasiswa Selama Penyusunan Skripsi di Stikes Aisiyah Yogyakarta. Skripsi. Yogyakarta: Program Studi Ilmu Keperawatan Stikes Aisiyah Yogyakarta. 2014.

16. Nashori F \& Diana R. Perbedaan Kualitas Tidur dan Kualitas Mimpi antara Mahasiswa Laki-laki dan Mahasiswa Perempuan. Indonesia Psycological Journal; 2012; 2 (2): 77-88.

17. Hariawan, H. Pengaruh berwudhu terhadap kualitas tidur lansia insomnia di PSTW Puspakarma Mataram. Thesis. Universitas Airlangga. 2015

18. Rinawati M. Pengaruh Terapi Wudhu sebelum Tidur terhadap Kejadian Insomnia pada Usia Lanjut di 
Dusun Tilaman Wukirsari Imogiri Bantul Yogyakarta. Yogyakarta: Sitikes Aisyiyah Yogyakarta. 2015.

19. Lela \& Lukmawati. Ketenangan: Makna Dawamul Wudhu (studi fenomenologis pada mahasiswa UIN Raden fatah Palembang. PSIKISJurnal Psikologi Islam. 2015; 1 (2): 55-66.
20. Matheer M. Kedahsyatan Manfaat Air Wudhu Berdasarkan Al-Quran dan As-sunah, Jakarta: PT Serambi semesta distribusi. 2015.

21. Zein SA. Refresh $\mathcal{E}$ Install Ulang Otakmu dengan Shalat. Yogyakarta: Sabil. 2015.

22. Sagiran. Mukjizat Gerakan Shalat. Jakarta: Qultum Media. 2012. 